\title{
Beinkröm hjá barni
}

\author{
Harpa Kristinsdóttir ${ }^{1}$ læknanemi, Soffía Jónasdóttir² læknir, Sigurður Björnsson² læknir, Pétur Lúðvígsson ${ }^{1,3}$ læknir
}

\section{ÁGRIP}

D-vítamín er mikilvægt fyrir eðlilegan beinvöxt og getur skortur leitt til beinkramar í börnum og beinmeyru í fullorðnum. Mikilvægasti D-vítamíngjafi á Íslandi er lýsi en erfitt er að̛ ná ráđlögðum dagsskammti D-vítamíns án lýsis eđa annars D-vítamíngjafa. Allmörg tilfelli beinkramar hafa greinst hér á landi á undanförnum árum en erlendar rannsóknir sýna að sjúkdómurinn er vaxandi vandamál um allan heim.

Hér er sagt frá stúlku sem greindist með beinkröm 27 mánaða gömul. Hún var á brjósti í tæpt ár og fékk D-vítamínviðbót með AD-dropum og porskalýsi en ekki í nægilegu magni. Fæðuofnæmi gerði pað að verkum að hún nærðist á einhæfu fæði sem innihélt takmarkað D-vítamín. Eftir greiningu var hafin háskammta D-vítamínmeðferð (Stoss meðferð) sem leiðrétti skortinn.

${ }^{1}$ Læknadeild Háskóla Íslands, ${ }^{2}$ Domus Medica, ${ }^{3}$ Barnaspítala Hringsins Landspítala.

Fyrirspurnir: Pétur Lúovígsson, Barnaspítala Hringsins Landspítala Hringbraut, 101 Reykjavík.

peturl@landspitali.is
Barst: 2. maí 2011, sampykkt til birtingar: 20. júní 2011.

Höfundar tiltaka hvorki styrki né hagsmunatengsl.

\section{Sjúkrasaga}

Móðir 27 mánaða stúlku leitaði með hana til barnalæknis og lýsti áhyggjum af einkennilegu göngulagi hennar og skökkum fótum. Við læknisskoðun var hún föl yfirlitum, lágvaxin (tafla I) og grönn fyrir aldur en foreldrar voru báđir hávaxnir. Hún hafði kjagandi breiðspora göngulag, dró fæturna eins og hún ætti erfitt með að lyfta peim og var laus í liðum með lina vöðva. Ofan við ökkla og úlnliði var pykknun á beini sem er eitt einkenni beinkramar og pví vaknaði grunur um beinkröm. Proskaáfangar á fyrsta ári voru innan eðlilegra marka. Fengin var röntgenmynd af mjöðmum, úlnliðum og hnjám og blóðrannsóknir sem sýndu væga lækkun á kalsíum í sermi, fosfat var innan eðlilegra marka en gildi alkalísks fosfatasa og kalkkirtlahormóns voru hækkuð og 25-hýdroxí-Dvítamín gildi lækkað (tafla II). Röntgenmyndir sýndu breikkaðar vaxtarlínur, gleikkun á nærkasti (metafysa) beina, skálarform á beinendum og mikla pynningu á beinum (mynd 1 og 2). Stúlkan var greind með beinkröm í samræmi við niðurstöður blóðrannsókna, röntgenmynda og læknisskoðunar.

Í heilsufarssögu kom fram að hún hafði haft exem frá fjögurra mánaða aldri en móðir og eldri bróðir voru einnig með exem. Við sjö mánaða aldur kom hún á bráđamóttöku barna vegna gruns um bráđaofnæmi. Ofnæmishúðpróf sýndu jákvæða svörun við eggjum, mjólk og fiski og foreldrar fengu næringarráðgjöf varðandi ofnæmisfæði. Ofnæmishúðpróf voru endurtekin við 14 mánaða aldur og sýndu pau jákvæða svörun við mjólk, eggjum, fiski, jarðhnetum og kasjúhnetum. Við 17 mánaða aldur fékk hún aftur bráðaofnæmi eftir að hafa komist í snertingu við hnetur og purfti meðferð á bráðamóttöku barna.

Farið var yfir mataræði og fæðusögu í leit að orsök fyrir beinkröm. Stúlkan var eingöngu á brjósti til fjögurra mánaða aldurs og öðru hvoru par til hún varð 11 mánaða. Í ljós kom að stúlkan fékk AD-dropa frá nokkurra vikna aldri fram að priggja mánaða aldri, í fyrstu einn dropa á dag en síðan hægt aukið upp í fimm dropa daglega. Frá priggja mánaða aldri fékk hún porskalýsi pví foreldrar vildu að hún fengi fitusýrurnar sem finnast í lýsi. Til að byrja með fékk hún einn dropa úr dropateljara en síðan vaxandi smám saman upp í fimm dropa. Eftir eins árs aldur fékk stúlkan eina teskeið af porskalýsi (tafla III) daglega, fyrir utan tveggja til priggja mánaða tímabil eftir að hún greindist með fiskiofnæmi, sökum hræðslu foreldra við að porskalýsi gæti orsakað ofnæmiseinkenni. Við sex mánaða aldur

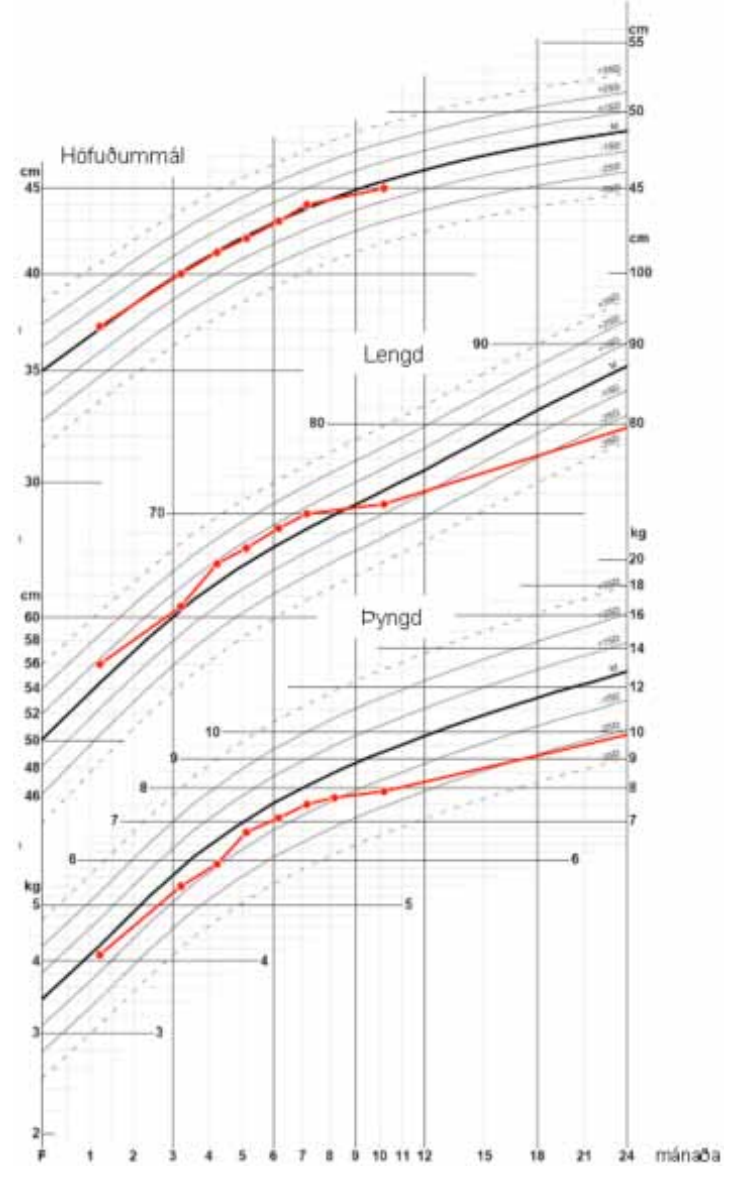

Tafla I. Vaxtarlínurit stúlkunnar til 24 mánaða aldurs. Hér sjást frávik frá pyngdarkúrfu við sex mánaða aldur og lengdarkúrfu við 11 mánaða aldur. 


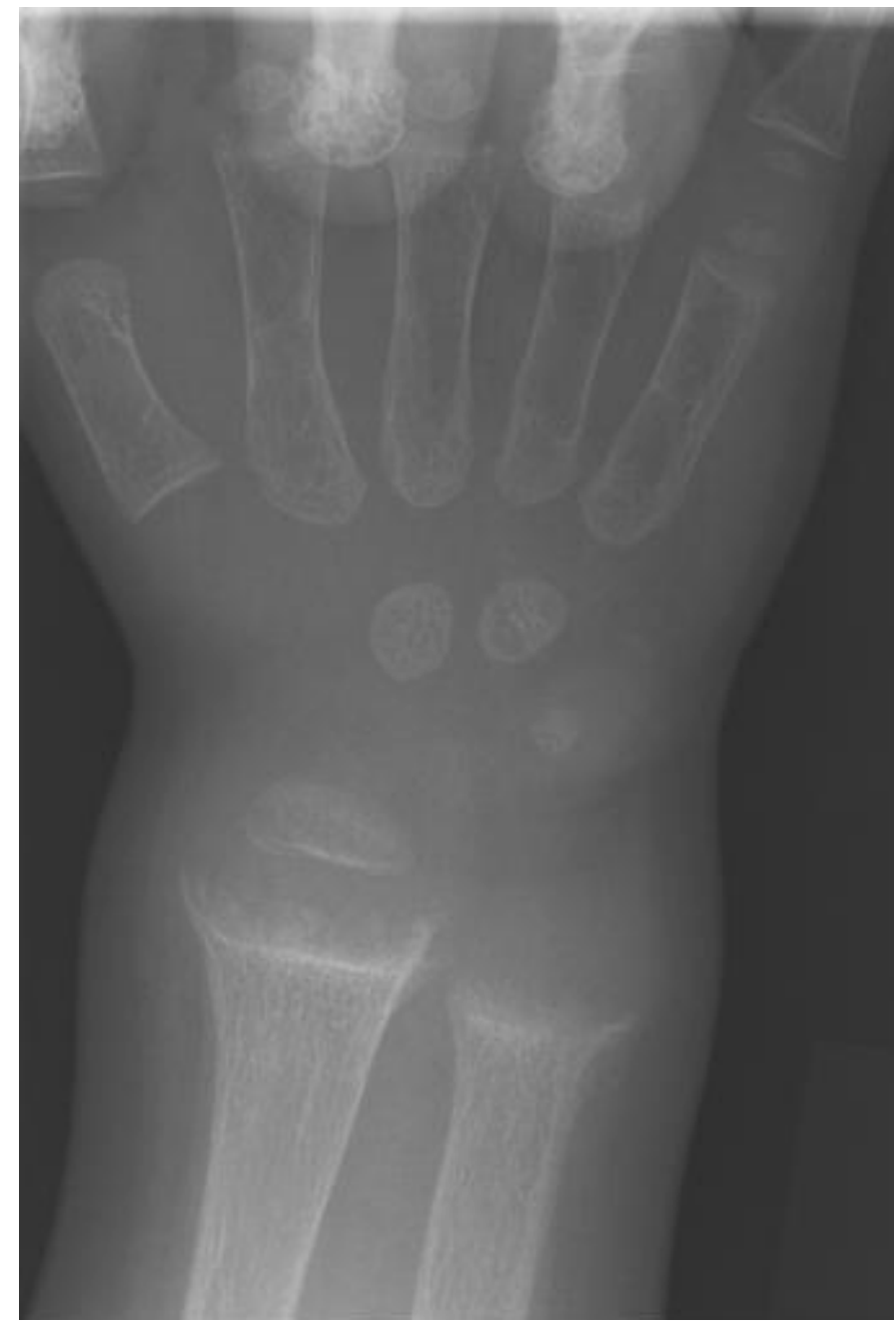

Mynd 1. Röntgenmynd af úlnlið tekin við greiningu á beinkröm. Vaxtarlinur eru mjög víðar og pað er gleikkun á nærkasti alnar (ulna) og sveifar (radius). Skálarform er á beinendum og mikil pynning á beini.

fór stúlkan að beygja af vaxtarkúrfu fyrir lengd og pyngd og við 10 mánaða aldur var foreldrum ráðlagt að auka við hana fæði. Раð gekk erfiðlega að innleiða fasta fæðu vegna mótstöðu hjá stúlkunni, hún geymdi matinn í munninum og neitaði að kyngja. Foreldrarnir sögðu hana nánast eingöngu vilja borða kolvetnaríkan mat og pá helst kartöflur.

Strax eftir greiningu á beinkröm gáfu foreldrarnir stúlkunni daglega 125 ug af D-vítamíni (5000 IU), auk teskeiðar af porskalýsi, par til hafin var háskammta D-vítamínmeðferð (Stoss-meðferð) mánuði síðar. Meðferðin var gefin í tvo daga og fólst í Calcium

Tafla III. Magn D-vítamíns i AD-dropum og porskalýsi borið saman.

\begin{tabular}{|c|c|c|c|}
\hline & $\begin{array}{l}\text { Ráðlagður } \\
\text { dagsskammtur } \\
\text { (RDS) samkvæmt } \\
\text { innihaldslýsingu }^{\text {a }}\end{array}$ & $\begin{array}{c}\text { Magn D-vítamíns } \\
\text { í RDS }\end{array}$ & $\begin{array}{l}\text { Magn D-vítamíns } \\
\text { i } 5 \text { dropum (um } \\
\text { paơ bil } 1 \mathrm{ml})^{\mathrm{b}}\end{array}$ \\
\hline AD-dropar & 5 dropar & $10 \mu \mathrm{g}$ & $10 \mu \mathrm{g}$ \\
\hline Porskalýsi & 1 teskeið $(5 \mathrm{ml})^{\mathrm{c}}$ & $9,2 \mu \mathrm{g}$ & $1,84 \mu \mathrm{g}$ \\
\hline \multicolumn{4}{|c|}{$\begin{array}{l}\text { a. Sérstakur dropateljari er seldur með AD-dropum. Dropateljarinn mælir einn millilítra } \\
\text { sem er um pað bil fimm dropar. } \\
\text { b. Í sjúkratilfellinu voru notaðir AD-dropar með } 400 \text { IU D-vítamíni í millilítra ( } 400 \mathrm{IU}=10 \\
\text { } \mu \mathrm{g} \text { ). } \\
\text { c. Ráðlagður dagsskammtur fyrir börn eins til fimm ára er ein teskeið af porskalýsi. }\end{array}$} \\
\hline
\end{tabular}

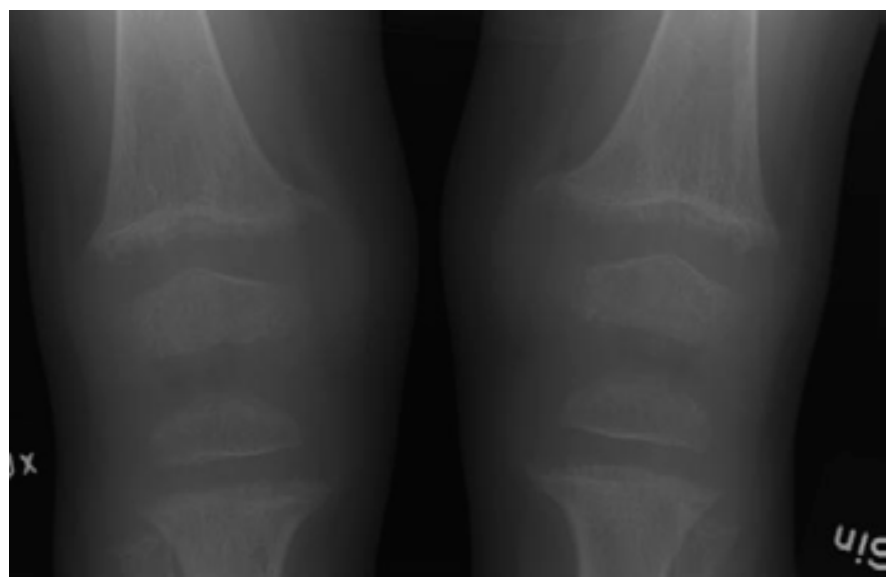

Mynd 2. Röntgenmynd af hnjám tekin við greiningu á beinkröm. Vaxarlínur eru mjög víðar og pað er gleikkun á nærkasti beggja vegna. Petta á við vaxtarlínur bæði á lærlegg (femur), sköflungi (tibia) og dálk (fibula). Skálarform er á beinendum og mikil pynning á beini.

Sandoz $250 \mathrm{mg}$ tvisvar á dag og 25-hýdroxí-D ${ }_{3}$-vítamíni $2500 \mu \mathrm{g}$ (100.000 IU) prisvar sinnum á dag. Eftir pennan hleðsluskammt af D-vítamíni var haldið áfram með Calcium Sandoz $250 \mathrm{mg}$ tvisvar á dag, par sem stúlkan fékk ekki kalk úr fæði sökum fæðuofnæmis gegn mjólk. Byrjað var aftur að gefa daglega skammta af D-vítamíni premur mánuðum eftir Stoss-meðferð eins og venja er.

Mikil aukning varð á 25-hýdroxí-D-vítamíni í sermi frá pví beinkröm var greind og stúlkan byrjaði að fá $125 \mu \mathrm{g}$ af D-vítamíni auk porskalýsis daglega, par til Stoss-meðferð hófst (tafla II). Bendir pað til að orsök beinkramar sé vegna of lítils D-vítamíns í fæðu og vanfrásog frá meltingarvegi sé ólíklegt. Ákveðið var að veita Stoss-meðferð prátt fyrir góða verkun af D-vítamíni um munn, par sem ekki er hægt að fylgjast með meðferð sem gefin er heima og auk pess hefur Stoss-meðferð reynst vel í meðferð á beinkröm. ${ }^{1}$

Í eftirfylgd premur vikum eftir Stoss-meðferð höfðu foreldrar tekið eftir auknum vöðvastyrk, stúlkan gekk meira og preyttist minna en áður. Auk pess virtist göngulagið ekki eins kjagandi.

\section{Umræður}

Í sjúkratilfellinu er sagt frá stúlku með fæðuofnæmi sem var á brjósti í tæpt ár og fékk D-vítamínviðbót í formi AD-dropa og porskalýsis. Hún fékk beinkröm vegna of lítillar D-vítamíninntöku vegna rangrar skömmtunar á porskalýsi og fæðuofnæmis sem kom í veg fyrir að hún fengi D-vítamín úr fæðu. Að 12 mánaða aldri fékk stúlkan í mesta lagi fimm porskalýsisdropa á dag í staðinn fyrir AD-dropa og er pað of lítið magn af D-vítamíni fyrir aldur (tafla III og mynd 3). Ráðlagður dagsskammtur fyrir D-vítamín er $10 \mu \mathrm{g} /$ dag fyrir 6-23 mánaða aldur og 7,5 $\mu \mathrm{g} /$ dag fyrir einstaklinga 2-60 ára samkvæmt norrænum næringarráðleggingum frá árinu 2004. ${ }^{2}$ Til að koma í veg fyrir beinkröm hjá börnum er talið nægjanlegt að pau fái $5 \mu \mathrm{g} / \mathrm{dag}$. ${ }^{3}$ Stúlkan í pessu sjúkratilfelli fékk í mesta lagi um 1,84 $\mu \mathrm{g} / \mathrm{dag}$ af D-vítamíni frá priggja mánaða aldri til eins árs. Horfur stúlkunnar eru góðar um að einkenni og beinbreytingar gangi algjörlega til baka. ${ }^{1}$

Á Íslandi er lýsi mikilvægasti D-vítamíngjafinn og er erfitt að ná ráðlögðum dagsskammti án lýsis eða annars D-vítamíngjafa.2, 4 
Tafla II. Niðurstöður blóðrannsókna við greiningu á beinkröm og eftir Stoss-meðferð.

\begin{tabular}{|c|c|c|c|c|c|}
\hline Blóðprufa & Tilvísun & $\begin{array}{l}\text { Beinkröm greinist við } \\
27 \text { mánaða aldur }\end{array}$ & $\begin{array}{l}\text { Fjórum vikum eftir } \\
\text { greiningu }\end{array}$ & $\begin{array}{l}\text { Níu dögum eftir Stoss- } \\
\text { meðferð }\end{array}$ & $\begin{array}{l}\text { Premur vikum eftir } \\
\text { Stoss-meðferð }\end{array}$ \\
\hline Hvít blóðkorn, x10E9/L & $4,5-11,5$ & 10,0 & & & 16,2 \\
\hline Blóðrauði (hemoglobin), g/L & $107-133$ & 113 & & & 122 \\
\hline Blóðkornaskil (hematocrit), L/L & $0,32-0,40$ & 0,36 & & & 0,38 \\
\hline Blóðflögur, x10E9/L & $150-400$ & 424 & & & 669 \\
\hline Meðalfrumurými (MCV), fL & $73-88$ & 83 & & & 81 \\
\hline Kalkkirtlahormón (parathyroid hormone), ng/L & $15,0-65,0$ & 522,9 & 239,7 & & 74 \\
\hline Fosfat, mmól/L & $0,85-1,50$ & 0,89 & 1,18 & 1,33 & 1,85 \\
\hline Kalsíum, mmól/L & $2,15-2,60$ & 2,04 & 2,22 & 2,43 & 2,50 \\
\hline Magnesíum, mmól/L & $0,71-0,94$ & & 0,91 & & \\
\hline Alkalískur fosfatasi, U/L & $120-540$ & 1146 & & 802 & 662 \\
\hline 25-OH-D vítamín, nmól/L & $>45$ & $<12,5$ & 110,7 & & \\
\hline 1,25-OH-D vítamín, nmól/L & $>45$ & & & & 61 \\
\hline Járn, $\mu \mathrm{mó} / / \mathrm{L}$ & $9-34$ & 8 & & & \\
\hline Járnbindigeta, $\mu$ mól/L & $49-83$ & 61 & & & \\
\hline Ferritín, $\mu \mathrm{g} / \mathrm{L}$ & $7-60$ & 54 & & & \\
\hline B12, pmól/L & $210-800$ & 242 & & & \\
\hline Transglútamínasi IgA, U/ml & $<5$ & & & $<3$ & \\
\hline Glúten IgG, g/L & $<105$ & & & 125 & \\
\hline Glúten IgA, g/L & $<7$ & & & $<2$ & \\
\hline Endomycial $\lg \mathrm{A}$ & neikvætt & & & neikvætt & \\
\hline
\end{tabular}

D-vítamínskortur getur haft alvarlegar afleiðingar í för með sér, eins og beinkröm hjá börnum og beinmeyru hjá fullorðnum. ${ }^{5}$ Algengi beinkramar á Íslandi hefur ekki verið rannsakað sérstaklega en allmörg tilfelli beinkramar hafa pó greinst hér á landi á undanförnum árum. Erlendar rannsóknir sýna að sjúkdómurinn er vaxandi vandamál um allan heim en hann var áður talinn sjaldgæfur og hverfandi. ${ }^{1,6}$

D-vítamín er forhormón sem getur myndast í húð eða er tekið upp í pörmum. Pegar 7-dehýdrókólesteról í húð kemst í snertingu við útfjólubláa B-geisla (með bylgjulengd 290320 nanómetrar) myndast $\mathrm{D}_{3}$-forvítamín sem síðar verður $\mathrm{D}_{3}$ vítamín (cholecalciferol) fyrir tilstuðlan sjálfkrafa handhverfingar (spontaneous isomerization) í húðinni. D-vítamín sem frásogast frá pörmum er á tveimur formum, $\mathrm{D}_{2}$-vítamín (ergocarciferol) sem fæst úr plöntum par sem pað er nýmyndað og $\mathrm{D}_{3}$-vítamín sem fæst úr húð spendýra par sem pað myndast líkt og hjá mönnum. $\mathrm{D}_{3}$-vítamín er allt að prisvar sinnum virkara en $\mathrm{D}_{2}$-vítamín. ${ }^{2}$ 7 Í lifur er báđum D-vítamín-forverunum breytt í 25-hýdroxíD-vítamín og í nýrum myndast virka formið 1,25-díhýdroxí-Dvítamín. Virka formið stjórnar kalkbúskap í líkamanum með pví að auka framleiðslu á kalkbindipróteini í smápörmum og tekur pátt í að viðhalda eðlilegum styrk kalsíums og fosfats í blóði og utanfrumuvökva. D-vítamín er mjög mikilvægt fyrir eðlilegan beinvöxt en auk pess hefur D-vítamínskortur verið tengdur við aukna sýkingatilhneigingu og við ýmsa sjálfsónæmissjúkdóma eins og iktsýki, sykursýki og sum krabbamein., 8

D-vítamínskortur skiptist í prjú stig eftir alvarleika. Á stigi eitt er 25-hýdroxí-D-vítamín lækkað, sem veldur lækkun á kalsíum í sermi, en 1,25-díhýdroxí-D-vítamín er hins vegar aukið eða óbreytt vegna afleiddrar kalkvakaofseytingar. Á stigi tvö er enn meiri lækkun á 25-hýdroxí-D-vítamíni og kalkkirtlahormónin halda áfram að reyna að halda uppi kalsíummagni með ofseytingu. Fosfat er lágt og pað er væg hækkun í alkalískum fosfatasa. Á priðja stigi er kominn alvarlegur skortur á 25-hýdroxí-D-vítamíni með lækkuðu kalsíum- og fosfatmagni í sermi og aukningu á alkalískum fosfatasa. Á pessu stigi eru komin fram einkenni beinniðurbrots sem sjást á röntgenmynd.

Vegna legu Íslands myndast D-vítamín ekki í húð yfir háveturinn. ${ }^{9}$ Fáar fæðutegundir innihalda D-vítamín en pó má nefna feitan fisk, sem inniheldur mikið af $\mathrm{D}_{3}$-vítamíni, og einnig innihalda eggjarauður eitthvað af pví. Hérlendis er ekki algengt

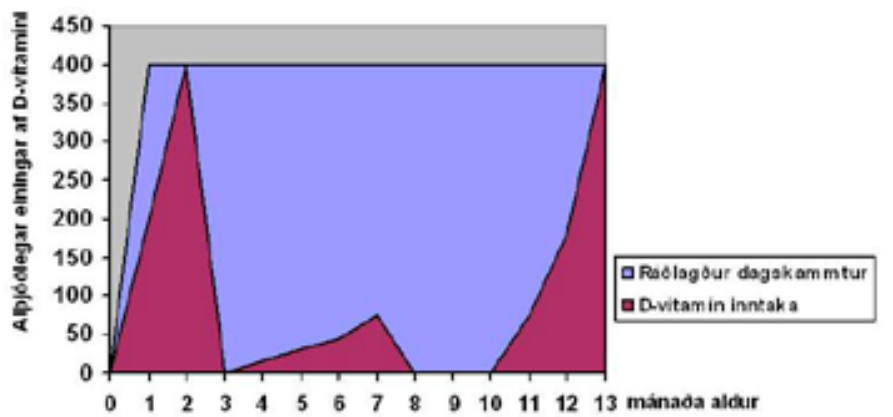

Mynd 3. D-vítamínneysla stúlkunnar miðað við ráðlagðan dagsskammt, frá fæðingu til 13 mánaða aldurs pegar hún fór að fá eina teskeið af porskalýsi á dag (RDS). 
að D-vítamínbæta matvörur en pað er algengt í öðrum löndum. ${ }^{10}$ Petta tilfelli undirstrikar mikilvægi D-vítamínuppbótar, ekki síst hjá ungum börnum. Heilbrigðisstarfsmenn purfa að hafa beinkröm og D-vítamínskort í huga, sérstaklega hjá börnum sem prífast illa og hjá börnum með fæðuofnæmi. Hægt er að koma í veg fyrir beinkröm hjá börnum með góðu eftirliti á heilsugæslustöðvum, reglubundinni kennslu heilbrigðisstarfsmanna og góðri fræðslu til foreldra og forráđamanna barna um mikilvægi D-vítamínuppbótar.

\section{Heimildir}

1. Misra M, Pacaud D, Petryk A, Collett-Solberg PF, Kappy M. Vitamin D deficiency in children and its management: review of current knowledge and recommendations. Pediatrics 2008; 122: 398-417.

2. Pedersen JI. Vitamin D requirement and setting recommendation levels - current Nordic view. Nutr Rev 2008; 66(10 Suppl 2): S165-9.

3. Gartner LM, Greer FR. Prevention of rickets and vitamin D deficiency: new guidelines for vitamin D intake. Pediatrics 2003; 111: 908-10.

4. Pórsdóttir I, Gunnarsdóttir I. D-vítamín í fæði ungra íslenskra barna. Læknablaðið 2005; 91: 581-6.
5. Wilton P. Cod-liver oil, vitamin D and the fight against rickets. CMAJ 1995; 152: 1516-7.

6. Holick MF. The vitamin D epidemic and its health consequences. J Nutr 2005; 135: 2739S-48S.

7. Cranney A, Horsley T, O'Donnell S, et al. Effectiveness and safety of vitamin $\mathrm{D}$ in relation to bone health. Evid Rep Technol Assess (Full Rep) 2007; 158: 1-235.

8. Zhang R, Naughton DP. Vitamin D in health and disease: current perspectives. Nutr J 2010; 9: 65.

9. Gunnarsson Ö, Indriðason ÓS, Franzson L, Halldórsdóttir E, Sigurðsson G. D-vítamínbúskapur fullorðinna Íslendinga. Læknablaðið 2004; 90: 29-36.
10. Calvo MS, Whiting SJ, Barton CN. Vitamin D fortification in the United States and Canada: current status and data needs. Am J Clin Nutr 2004; 80(6 Suppl): 1710S-6S.

\section{ENGLISH SUMMARY}

\section{Rickets in a child}

Kristinsdóttir H, Jónasdóttir S, Björnsson S, Lúðvígsson P

Vitamin D is necessary for normal bone growth. Deficiency of vitamin D can lead to rickets in children and osteomalacia in adults. It is difficult to reach the recommended daily dose of vitamin D in children without cod liver oil or other vitamin D supplementation. Several cases of rickets have been diagnosed in Iceland the past few years. Studies suggest a worldwide increase in the prevalence of the disorder.

We report on a girl who was diagnosed with rickets at the age of 27 months. She received inadequate amounts of vitamin $D$ supplementation in the form of $A D$ drops and cod liver oil. Because of food allergy she was on a restricted diet which limited her intake of dietary vitamin D. After diagnosis, she received a high-dose vitamin $\mathrm{D}$ therapy (Stoss therapy) which corrected the deficiency.

Key words: rickets, food allergy, vitamin D.

Correspondence: Pétur Lúðvígsson, peturl@landspitali.is 